\title{
Metrication and the falling yen
}

The General Accounting Office (GAO) in Washington is plainly as puzzled as the rest of the world that so little has happened to make the metric system a reality in the United States. The falling yen will prolong the puzzle.

Historically, the surprise is that the United States did not go metric at the outset, given the French influence on the conduct of the War of Independence that threw out the British. Since then, there have been many false starts. Congressional procedures have, over the years, encouraged a steady stream of bills aimed at rationalizing the irrational, making it easier for those who learned to count in tens also to know by how much they are breaking the speed-limit (still a maximum of 55 miles an hour) or, more usefully, to translate a tonnage of oil spilled off the coast of Alaska into a volume. The latest development, and that which has stirred GAO into action, is an amendment tagged onto the Trade and Competitiveness Act of 1988 (which also sanctions US action against unfair trading partners) giving federal agencies until 1992 to use the metric system in their procurement of supplies.

What emerges from GAO's enquiry is simple; the administration does not have its heart in metrication. Not that the bureaucracy has been entirely neglectful. The Department of Commerce has been nominated as the "lead agency", and has dutifully set up two interagency committees. The department has also provided terms of reference for ten other committees, and has appointed chairmen for nine of them. But only one committee (that for the construction industry) has met - on three occasions. If there are white sheep among the 37 agencies surveyed, they are the Nuclear Regulatory Agency (which hopes to be finished in 1997) and the Department of Defense (which has more than a single official working on the project).

GAO seems also to have identified a sense of urgency at the National Aeronautics and Space Administration (NASA), which is reported to be concerned that the multinational space station should fit properly together even though some parts, the Hermes spacecraft, for example, will be built in France. With characteristic prudence, NASA estimates that the cost of metrication on the space station will be $\$ 200$ million. A few more numbers like that, and even the Congress will be found to be cooling on the whole idea.

What GAO now wonders is whether the Department of Commerce should be given stronger powers to coerce federal agencies to meet deadlines it imposes. That, no doubt, would help, but not much. The plain truth is that the United States is not yet ready for metrication. Those who trade corn (in bushels) or buy gasoline (in gallons) are too fond of their present ways. It might well have been different if the yen were not falling with the Tokyo Stock Exchange, or if Mrs Carla Hills, the US Trade Representative, had not last week won her well-advertised and well-staged battle with the Japanese over trade. The truth is that US alarm about competiteveness is not constant. What seems to matter - and to hurt - are the mutually cancelling trade deficits and the scale of Japanese investment in US real estate. Now, no doubt temporarily, both are falling, so that competitiveness and metrication with it are pushed into the background. But the falling yen means that the trade deficit will soon increase again, when metrication will no doubt come into its own once more. Meanwhile, the biggest danger is that the construction industry's zealous committee will make such progress, and the others will make so little, that building accessories will not fit together as they should.

\section{Jones bows out}

The Australian government has lost an able minister with the decision to drop its science minister.

THE departure of Mr Barry Jones, minister of science in the Australian government until last week, when he was dropped against his wishes (see page 577), is a sad business. Jones, too often described as "colourful", is in reality a serious person who has done a power of good for Australian science. His consistent message in office has been that Australia, with the conviction that it must make its way in the world by being at least as smart as its competitors, has awakened both the government and substantial parts of Australian industry to the need for greater investment in research and modern industrial innovation. That too few may have listened to him is not his fault. He has also pushed hard, and sometimes successfully, for projects that will seriously enliven the Australian scene, notably the University of Sydney's stellar interferometer, due to be commissioned later in the year. It may be true that Jones managed to cut only a poor approximation to the standard figure of a politician, but that - many people would say - may have been his strength. It is unfortunate that Mr Bob Hawke, the prime minister, not himself the most polished of politicians, should have been unable to make better use of Jones's energy and enthusiasm. 